VERTAISARVIOITU

KOLLEGIALT GRANSKAD

PEER-REVIEWED

www.tsv.fi/tunnus

\title{
"SAAKO MUSTAN TUSSIN?" OPPILAIDEN PYYNNÖT VENÄJÄNKIELISESSÄ CLIL-ALKUOPETUKSESSA
}

\author{
Maarit Kaunisto, Helsingin yliopisto
}

Tässä artikkelissa tarkastellaan oppilaiden pyyntöjä venäjänkielisessä CLIL-alkuopetuksessa. Tutkimusaineisto koostuu kahden vuoden aikana videonauhoitetuista aidoista vuorovaikutustilanteista. Pyyntöjä tarkastellaan keskustelunanalyyttisesti vieruspareina, joissa etujäsen muodostuu yleensä oppilaan tuottamasta pyynnöstä ja jälkijäsen pyynnön hyväksymisestä tai hylkäämisestä. Sosiokulttuurisen ja tilanteisen oppimisen teorioiden pohjalta oletuksena on, että oppilaat sosiaalistuvat oman yhteisönsä toimintaan kahden alkuopetusvuoden aikana toimimalla yhdessä ja osallistumalla vuorovaikutuksessa opettajan ja vertaisoppijoiden kanssa. Jo ensimmäisen vuoden keväällä oppilaiden aloittamat pyynnöt muuttuvat lähes täysin venäjänkielisiksi johtuen todennäköisesti yhteisesti solmitun kielisopimuksen sisäistämisestä. Kielisopimuksella tarkoitetaan sitä, että oppilaiden edellytettiin ilmaisevan pyyntönsä kohdekielellä, venäjäksi (second language, L2). Kahden vuoden aikana oppilaat kehittyvät myös pyyntöjen rakenteellisessa muotoilemisessa käyttäen apunaan opettajan tarjoamia malleja ja rakennekehyksiä. Tutkimus osoittaa, että vuorovaikutustilanteissa voidaan omaksua sisällön ohessa myös kohdekielen rakenteita, sanastoa ja kielenkäyttöä sekä kielisopimuksen avulla ohjata oppilaiden toimijuutta kielen oppimisen näkökulmasta oikeaan suuntaan.

Avainsanat: CLIL, keskustelunanalyysi, luokkahuonevuorovaikutus, pyyntö, rakennekehys, venäjä

\section{JOHDANTO}

Kielenopetus mielletään yleensä nimenomaan kielen avulla tapahtuvaksi toiminnaksi, mutta kieltä voi oppia myös muun toiminnan ohessa mielekkään käytön kautta luonnollisessa vuorovaikutuksessa. Tällaisen mahdollisuuden voi tarjota CLIL-opetus (Content and Language Integrated Learning),

Kirjoittajan yhteystiedot:

Maarit Kaunisto

maarit.kaunisto@helsinki.fi jossa osa oppisisällöistä opetetaan oppilaille vieraalla kielellä (esim. Dalton-Puffer \& Smit, 2013; Kalliokoski, Mård- Miettinen \& Nikula, 2015; Salehova \& Grigor'jeva, 2016). Euroopassa CLIL-opetuksen kohdekielenä (target language) on yleisimmin kansainvälinen valtakieli englanti (Nikula \& Moore, 2016). Tässä artikkelissa tutkittavan alkuopetusryhmän (6-8-vuotiaat) kohdekielenä eli opetus- ja toimintakielenä on venäjä, jota ei ole ennen tutkittu CLIL- kontekstissa. Tutkimus fokusoituu luonnollisessa CLILluokkahuonevuorovaikutuksessa esiintyviin oppilaiden tuottamiin pyyntöihin sekä vuo- 
rovaikutuksen rakentumisen että itse pyyntörakenteen kehittymisen näkökulmasta.

Vaikka luokkahuoneen vuorovaikutus on aina jossakin märin institutionaalisten osallistujaroolien (opettaja ja oppilas) sävyttämää (Tainio, 2007), voidaan sielläkin oppilaskeskeisten ja toiminnallisten aktiviteettien avulla muovata vuorovaikutusta arkikeskustelunomaiseksi ja osallistujien puheoikeuksien osalta tasa-arvoiseksi. Tarkastelun kohteena olevassa luokassa käydään tietynlaista pedagogisesti virittynyttä institutionaalista roolileikkiä. Tämä tarkoittaa sitä, että oppilaat voivat vapaasti käydä asioimassa eli pyytämässä esimerkiksi tarvitsemaansa materiaalia opettajalta. Opettaja puolestaan voi hyödyntää tällaisen asiointilanteen tarttumalla oppilaan pyyntöön myös kielellisestä näkökulmasta. Roolileikkiin kuuluu myös kielisopimus, jonka mukaan CLIL-tunnilla käytetään opettajan ja oppilaan välisenä vuorovaikutus- ja asiointikielenä venäjää. On kuitenkin huomioitava, että oppilaiden kakkoskielisyys (second language, L2) voi aiheuttaa haasteita vuorovaikutustilanteissa (Kurhila \& Laakso, 2016).

Direktiivejä ja niiden alakäsitteeksi luokiteltuja pyyntöjä on tutkittu erityisesti 1980-luvulta lähtien sekä arkikeskustelussa että institutionaalisessa keskustelussa. Arkikeskustelun tutkimusta varhaisessa kielenoppimiskontekstissa edustavat mm. Kauppisen (1998) ensikielen kehitystä tarkasteleva työ, Wong-Fillmoren (1979) vertaisvuorovaikutusta tarkasteleva tutkimus sekä Savijärven (2011) kielikylpypäiväkodin arkitilanteisiin fokusoitunut pitkittäistutkimus. Yläluokkalaisten pyyntöjä vertaisoppijanäkökulmasta CLIL-opetuksessa on keskustelunanalyyttisesti tutkinut Jakonen (2015). Myös Dalton-Pufferin ja Nikulan $(2006,2007)$ diskurssianalyyttiset tutkimukset suuntautuvat yläluokkiin, joissa tarkastelun kohteena on englannin kielellä opettavan CLIL-opettajan käyttämät direktiivit. Savijärven (2011) keskustelunanalyyttinen tutkimus tuo esiin varhaisessa toisen kielen oppimisen kontekstissa tärkeät rakennekuviot, joita suomenkieliset lapset hyödyntävät ruotsinkielisiä ilmauksia (usein pyyntöjä) tuottaessaan. Kauppisen useamman vuoden aikana kerätty tutkimusaineisto on niin ikään empiiristä, vaikka itse menetelmää ei siinä keskustelunanalyysiksi kutsuta. Sama pätee Wong-Fillmoren tutkimukseen, jossa luonnollista vertaisvuorovaikutusta tarkastellaan hyvin yksityiskohtaisesti menetelmällä, joka muistuttaa keskustelunanalyysiä. Tässä artikkelissa sivutaan myös suomen kielen direktiivejä siitä syystä, että informantit ovat suomenkielisiä ja tuottavat aluksi ilmaisuja enimmäkseen suomeksi. Tanner (2012) vertailee vuorovaikutuksen näkökulmasta asiointitilanteisiin liittyviä pyyntöjä suomi toisena kielenä-oppikirjamateriaaleissa ja autenttisissa vuorovaikutustilanteissa fokusoiden pyyntösekvenssien kielellisiin rakenteisiin. Laurannon (2015) tutkimuksen keskiössä on erityisesti suomen kielen imperatiivin rakenne ja sen funktionaalinen käyttö.

Pyyntöjen venäjänkielistä tutkimusta työssäni edustavat Boldenin (2017) ja Yli-Piiparin (2002) tutkimukset. Yli-Piiparin lähinnä kohteliaisuusteoriaan nojautuvassa lisensiaatintyössä tarkastellaan keskustelunanalyysiä soveltaen venäjänkielisissä ja suomenkielisissä elokuvakäsikirjoituksissa esiintyviä pyyntöjä ja niiden suomennoksia/venäjännöksiä. Yli-Piiparin aineisto ei koostu luonnollisesta vuorovaikutuksesta (vaikka hänen mukaansa muistuttaa spontaania keskustelua), mutta vertaileva näkökulma suomen ja venäjän puhutussa kielessä esiintyviin pyyntöihin on kiinnostava. Boldenin (2017) keskustelunanalyyttinen tutkimus Amerikassa asuvien venäjänkielisten aikuisten arkikeskustelusta illallispöydän äärellä osoittaa imperatiivirakenteisen pyynnön ylivallan lähes kaikissa vuorovaikutustilanteissa (ks. myös Yli-Piipa- 
ri, 2002).

Tämän tutkimuksen aineisto on kerätty kahden vuoden aikana videoimalla luonnollisia vuorovaikutustilanteita oppilaiden itsenäisen työskentelyn mahdollistavilta käsityötunneilta. Työn metodiksi on valittu keskustelunanalyysi, jota täydennetään jonkin verran pitkittäisnäkökulmalla sekä etnografisilla havainnoilla. Luonnollista puheaineistoa hyödyntävässä luokkahuonevuorovaikutukseen liittyvässä kielentutkimuksessa keskustelunanalyysi on maailmanlaajuisesti jo vakiintunut menetelmä (ks. esim. Markee, 2015). Sen sijaan puhutun venäjän kielen tutkimus on 2000-luvulle asti ollut rajoittunut perinteiseen kieliopilliseen tutkimukseen (esim. Mustajoki, 2006; Nikunlassi, 2011; Paukkeri, 2006).

Toisen kielen tutkimuksen (Second Language Acquisition, SLA) kentällä on siis selkeästi tarvetta sellaiselle alaluokkiin suunnatulle tutkimukselle, jossa CLIL-opetuksen kohdekielenä tarkastellaan muuta kieltä kuin englantia (esim. Harklau, 2011). Ylipäätään nuoriin venäjän oppijoihin suunnattua tutkimusta on Suomessa tehty erittäin vähän (ks. kuitenkin Kuikka, 2001, venäjä vieraana kielenä -oppijoiden tyypilliset virheet ja Jurkov, Protasova, Popova \& Nikunlassi, 2012, venäjä toisena kielenä- oppijoiden kommunikatiivisen kompetenssin muotoutuminen). Myös pitkittäistutkimusta peräänkuulutetaan (esim. Dalton-Puffer \& Smit, 2013; Markee, 2015; Pekarek Doehler, Wagner \& GonzalezMartinez, 2018; Taleghani-Nikazm \& Huth, 2010). Tämän työn tarkoitus onkin osaltaan täyttää näitä SLA-tutkimuksen aukkoja.

On perusteltua olettaa, että institutionaalisessa kieliluokkakontekstissa syntyneet autenttiset kielenkäyttötilanteet kasvattavat oppilaiden mahdollisuuksia legitimoida osallistumisensa yhteisönsä sosiaaliseen toimintaan. Myös kielisopimus ohjaa ja rohkaisee oppilaita käyttämään venäjää muun toiminnan yhteydessä. Oikeutettua osallistumista edesauttavat oppilaiden tasaveroiset mahdollisuudet tehdä kohdekielisiä aloitteita esimerkiksi pyytämällä vapaasti tarvitsemiaan materiaaleja tai apua työnsä eri vaiheissa. Sosiokulttuurisen ja tilanteisen oppimisen teoriat (Lantolf \& Poehner, 2008; Lave \& Wenger, 1991) tukevat hypoteesia siitä, että arjen tilanteissa toistuva ja vuorovaikutteinen osallistuminen johtanee tutkittavana olevassa CLIL-luokassa itsenäiseen kohdekielen käyttöön pitkällä aikavälillä. Lisäksi esitän, että opettajan tarjoamat kielelliset rakennemallit johtavat ajan mittaan oppilaiden itsenäiseen kielelliseen tuottamiseen eli oppimiseen niitä hyödyntäen. Tästä syystä kehittyvän kielen tarkastelu sekä pyyntörakenteena että sosiaalisena toimintana kaikkine yksityiskohtineen ja todellisessa käytössään on perusteltua (esim. Drew \& Couper-Kuhlen, 2014).

Seuraavaksi esittelen lyhyesti tutkimukseni teoreettisen viitekehyksen. Itse pyyntöä tarkastelen oppilaan näkökulmasta sekä vuorovaikutuksen sosiaalisena resurssina että rakenteellisena kuviona. Analyysiosiossa vastaan seuraaviin tutkimuskysymyksiin: Millä kielellä pyynnöt esitetään? Mitä rakenteita pyynnön sisältävissä vuoronvaihtojaksoissa esiintyy?

\section{ARKIKOKEMUKSET YMMÄRRYKSEN JA OSALLISTUMISEN TAUSTALLA}

Lapsen kielellinen kehitys kulkee aluksi toiminnasta kieleen. Vaikka kouluiässä opetuksella on keskeinen merkitys, käsitteitä ei voida opettaa nyrkkisääntöinä, vaan lapsen on ne itse luotava omien ajatusprosessiensa kautta (Vygotsky, 1978; Vygotsky, 1982). Vygotskyn ajatuksia tulkinneet Negueruela (2008) sekä Lantolf ja Poehner (2008) myöntävät aktiivisuuden ja sosiaalisen vuorovaikutuksen merkityksen, mutta heidän mukaansa 
mikä tahansa aktiviteetti ei kuitenkaan johda kehittymiseen, vaan tarvitaan ohjausta ja tietoista harjoittelua. He myös esittävät, että kielen omaksumiseen tarvitaan kokonaisvaltaisia ja konkreettisia aktiviteettejä, joiden yhteydessä käsitettä voidaan verbalisoida samalla toimien (Lantolf \& Poehner, 2008; Negueruela, 2008).

Lev Vygotskyn (1978, s. 52-53) ajatusten perusteella syntyneen ja sosiokulttuuriseksi oppimisen suuntaukseksi nimetyn teorian mukaan ohjattu ja tuettu sosiaalinen vuorovaikutus on välittynyttä toimintaa, jossa tarvitaan sekä symbolisia välineitä (symbolic tools) että välittäviä keinoja (mediating tools). Symbolisena välineenä käytetään esimerkiksi kieltä. Välittävät keinot voivat olla luonteeltaan sosiaalisia, jolloin toistuva ja tavoitteellinen osallistuminen yhteisön kulttuurisiin aktiviteetteihin johtaa ajattelun taitojen kehittymiseen myöhemmin yksilöllisellä tasolla (Lantolf \& Thorne, 2006; NegueruelaAzarola, Garcia \& Buescher, 2015; Thorne \& Hellermann, 2015). Vygotskyn (1978) mukaan arjen vuorovaikutustilanteissa hankitut käsitteet luovat pohjan ymmärrykselle ja oppimiselle.

Yhteisölliseen koululuokkaan sovellettavissa oleva tilanteisen oppimisen teoria lähestyy oppimista arkitilanteisiin osallistumisen kautta. Oppivan ja harjoittelevan yhteisön jäsenten osallistuminen on aluksi oikeutettua perifeeristä, mutta muuttuu ajan kuluessa oikeanlaisen ohjauksen ja tuen myötä täysivaltaiseksi osallistumiseksi (Lave \& Wenger, 1991). Vaikka tilanteisen oppimisen viitekehyksessä ei korosteta niinkään kielen merkitystä sosiaalisessa vuorovaikutuksessa, voidaan sitä soveltaa (esim. Savijärvi, 2011) yhteisönä oppivaan koululuokkaan, jossa hankitaan arkikokemuksia tekemällä ja osallistumalla, myös kielellisesti.

\section{PYYNTÖ SOSIAALISENA RESURSSINA JA RAKENTEELLISENA KUVIONA}

Pyyntöjen yläkäsitteellä eli direktiivillä tarkoitetaan ohjailevaa lausumaa tai toimintaan kehottamista (esim. Lauranto, 2015; Nikunlassi, 2011), jolla voidaan manipuloida vastaanottajan käytöstä ja saada tällä tavalla hänet tekemään pyytäjälle edullisia asioita (esim. Drew \& Couper-Kuhlen, 2014). Enfieldin (2014) mukaan pyyntöjen esittäminen edellyttää kuitenkin esisosiaalista ja yhteistoiminnallista orientaatiota ja yhteistä sitoutumista. Myös Lauranto (2015) esittää, että arjen tilanteissa pyynnön avulla voidaan toiminnasta tehdä yhteistä eikä pyytämisellä yllämainitusta manipuloinnin olemuksestaan huolimatta ole tekemistä epäsymmetrisen valtahierarkian kanssa. Pyyntödirektiivillä on näin ollen merkittävä sosiaalinen tehtävä.

Vaikka oppilaiden pyyntöjä tarkastellaan erityisesti vuorovaikutuksen rakentumisen näkökulmasta, on perusteltua kiinnittää huomiota myös niiden muodostamiseen. Pyyntö voidaan ilmaista rakenteellisesti erilaisin keinoin. Seuraavaksi luon yleiskatsauksen suomen ja venäjän kielessä esiintyviin lingvistisiin pyyntörakenteisiin. Pyyntöjen rakenteellisessa tarkastelussa hyödynnän erityisesti Tannerin (2012), Kauppisen (1998), Wong-Fillmoren (1979), Savijärven (2011), Boldenin (2017) ja Yli-Piiparin (2002) tutkimuksia.

Tanner (2012) tarkastelee asiointiaineistossaan pyyntöjen funktionaalisuutta jakamalla ne karkeasti kahteen luokkaan: tuotepyynnöt ja palvelupyynnöt. Rakenteellisesti hän erottelee pyynnöistä erilaisia suomen kielelle ominaisia modaalisia lausetyyppejä, väitelauseen muotoisia pyyntöjä, kysymyslauseita, imperatiivimuotoisia pyyntöjä sekä finiittiverbittömiä nominilausekkeita. Kauppisen tutkimuksessa (1998) ensikielen omaksumi- 
nen ei tarkoita vain näitä rakenteellisia ominaisuuksia. Lapsen puheessa esiintyy puhekuvioita, joihin liittyy myös tilanteen, affektin ja puheen funktion yhteys. Kauppisen mukaan pragmaattiset sävyt ovat lapselle merkityksellisiä, ja hän pyrkii siksi löytämään toiminnan ja siihen yhdistyvän kielellisen tapahtuman välille yhteyden. Toistuvan puhekuvion lisäksi merkitystä on joustavalla rakennekehyksellä, joita kielenoppija voi hyödyntää tilanteen mukaan siirtäen opitun puhekuvion tai osan siitä puuttuviin aukkoihin tai korvaten puhe-elementin jollakin toisella (Kauppinen, 1998).

Wong-Fillmore (1979) on pitkittäistutkimuksessaan havainnut, että kielitaidon ollessa lähes olematon tai ainakin hyvin niukka, lapset käyttävät aluksi erilaisia sosiaalisia resurssejaan korvatakseen kognitiivisia, kielitaitoon liittyviä puutteitaan (ks. myös Myles, Hooper \& Mitchell, 1998). Wong-Fillmore (1979) nimeää tällaisiksi selviytymisresursseiksi esimerkiksi ymmärtämisen teeskentelyä, arvauksia, jäljittelyä, kielellä leikittelyä, rutiinifraaseja (esim. Saako mennä vessaan? omassa aineistossani), holististen rakennekuvioiden (formulaic utterances) käyttöä sellaisenaan tai joustavana rakennekehyksenä (formulaic frame). Yksittäisiä sanoja tai kiinteitä fraaseja laajempaan rakennekehykseen voidaan sijoittaa jo omaakin tuotosta (esim. antakaa, olkaa hyvä, vanua tai saako mustan tussin? tämän tutkimuksen aineistosta, kursiivilla oppilaan täysin oma tuotos). Vaikka Wong-Fillmore painottaa näiden rakennekuvioiden tai -kehysten sosiaalista luonnetta vertaisvuorovaikutuksessa, hän myös kuvaa niitä kieliopillisesti.

Savijärvi (2011) korostaa sitä, että opettajan tehtävä on lähes kaiken toiminnan kielentäminen. Erityisesti kielikylpytyyppisessä toiminnassa kielisyötettä on tarjottava runsaasti. Hänen aineistossaan päiväkodin suomenkieliset kielikylpylapset esittivät pyyntöjä aluksi imitoiden samoina toistuvia pyyntökuvioita sellaisenaan. Myöhemmin he oppivat käyttämään useaan kertaan "maistelemaansa" rakennekuviota jo pyyntönä, joita he tuottivat oma-aloitteisesti. Seuraavassa vaiheessa lapset käyttivät tätä mallia niinikään joustavana rakennekehyksenä (ks. Wong-Fillmore, 1979) kierrättäen kieliainesta sellaisenaan tai varioiden (Savijärvi, 2011). Jatkossa käytän termiä rakennekehys tarkoittaessani yllä kuvattuja, opettajan mallintamia pyyntörakenteita, joita oppilas voi luovasti täydentää.

Toisin kuin suomen kielessä (ks. Lauranto, 2015; Tanner, 2012) pyyntö ilmaistaan venäjän kielessä yleisimmin imperatiivimuotoisella verbillä niin muodollisissa tilanteissa kuin arkikeskusteluissakin (ks. Bolden, 2017; Mustajoki, 2006, s. 259; Yli-Piipari, 2002). Tosin pyyntö voidaan esittää lukuisin muinkin tavoin (ks. Mustajoki 2006, s. 258-260; Yli-Piipari, 2002, s. 25). Venäjän kieliopin (RG, 1980, \$1475) mukaan prototyyppinen imperatiivi muodostetaan siten, että monikon 3. persoonan preesensin vartaloon lisätään imperatiivin pääte yksikön tai monikon 2. persoonassa (esim. daj/te, annalantakaa). 2. persoona voi monikollisuuden lisäksi esiintyä teitittelymuotona, jota käytetään venäjän kielessä yleisesti (ks. esim. Yli-Piipari, 2002). Joskus suoraa pyyntöä ilmaisevan imperatiivirakenteen yhteydessä käytetään pehmentävänä elementtinä partikkelia požalujsta (ole) olkaa hyvä, englanniksi please) (Bolden, 2017, 196).

Toinen melko yleinen tapa pyytää konkreettista asiaa itselle tietyssä tilanteessa (ks. Bolden, 2017; Mustajoki, 2006; Yli-Piipari, 2002) on rakenne: Možno kružkupiva? Saako tuopin olutta? (esimerkki Mustajoki, 2006, s. 260). Tässä yhteydessä možno/saako on persoonaton muoto modaaliverbistä moč (voida) eli adverbimuotoinen predikatiivi (RG, 1980, \$1653), jonka ensimmäisellä vokaalilla on sekä nouseva että laskeva intonaatio (Oja- 
nen, 1972; RG, 1980, \$153; ks. myös Bolden, 2017).

\section{TUTKIMUSASETELMA, -AINEISTO JA METODI}

Tämän tapaustutkimuksen aineisto on kuvattu yhdellä kameralla. Aineisto koostuu luonnollisista vuorovaikutustilanteista venäjänkielisiltä CLILoppitunneilta, joilla aktiviteetit ovat luonteeltaan itsenäistä, vapaamuotoista työskentelyä käsityön parissa. Tutkimusjoukkona on 18 suomenkielisen oppilaan (11 poikaa ja 7 tyttöä) ryhmä, joka opiskelee venäjää ensimmäisenä vieraana kielenä (FL, foreign language). Oppilaiden äidinkieli (L1, first language) on suomi. Pitkittäistutkimuksen aikana lapset ovat 6-8-vuotiaita. Venäjänkielinen opetus toteutuu laajamittaisena kaksikielisenä opetuksena (POPS 2014, luku 10) ja lisäksi oppilaat saavat viisi formaalia kielen opetustuntia viikossa syntyperäisen kielenpuhujan johdolla. Oppilaiden kielitaito on tutkimuksen alkaessa kuitenkin vielä hyvin niukka.

Oppilaiden tekemistä aloitteista pyyntöjä esiintyy aineistossa eniten ja siksi ne tarjoutuvat luontevasti tutkittaviksi. Oppilaiden tuottamat venäjänkieliset pyynnöt motivoituvat ei-syntyperäisen opettajan mallinnoksista. Opettaja on suomenkielinen ja puhuu venäjää niin kuin sitä on hänelle vieraana kielenä opetettu. Tosin hän on työssään hankkinut hyvän suullisen kielen taidon erityisesti luokkakielessä, jolla tarkoitetaan arjen toimintakieltä luokkahuoneessa. Opettaja tarjoaa oppilaille runsaasti kielisyötettä venäjäksi (L2) samalla kuitenkin yksinkertaistaen ja välttäen tietoisesti sellaisia rakenteita, joita oppilaat eivät vielä osaa. Opettaja haluaa kuitenkin opettaa heille myös pragmaattisesti hyväksyttävää, kohteliasta kielenkäyttöä mallintamalla heille pyyntöjen muodostamista lähinnä kahdella tavalla: aluksi oppilaille helpommalla možno/ saako- rakennekehyksellä ja myöhemmin kohteliaammalla imperatiivimuotoisella rakennekehyksellä. Tämän lisäksi opettaja ohjaa oppilaita käyttämään teitittelymuotoa sekä kohteliaisuusilmaisinta (dajte požalujstalantakaa olkaa hyvä). Tutkija-opettajan lisäksi oppitunteihin osallistuu joskus toinen opettaja tai venäjänkielinen avustaja.

Tarkemman analyysin kohteeksi on valittu viisi sekvenssiä, joista kaksi sijoittuu ensimmäiselle alkuopetusvuodelle ja kolme toiselle. Sekvenssillä tarkoitetaan tässä työssä sellaista vuorovaikutuskokonaisuutta, joka koostuu useasta pyynnön sisältävästä vuoronvaihtojaksosta. Tutkittavien sekvenssien valikoitumisen perusteena on se, että niissä kaikissa esiintyy samankaltainen tuntiaktiviteetti. Kaiken kaikkiaan tällaista vuorovaikutusta nauhoitettiin ja litteroitiin 90 minuuttia. 85 esimerkistä koostuva pyyntökokoelma muodostuu osasta tästä eli 55 minuutin pituisesta, tarkasti litteroidusta ja analysoidusta luokkahuonevuorovaikutuksesta. Litteraateissa esiintyvien osallistujien nimet ovat pseudonyymejä.

Aineisto on analysoitu keskustelunanalyyttisesti. Tämän metodin mukaisessa sekvenssijäsennyksessä minimaalisena puheen rakennusyksikkönä toimii kiinteä, kahden eri puhujan peräkkäisistä vuoroista muodostuva vieruspari (esim. Schegloff, 2007). Tässä työssä oppilaan pyyntö voi esiintyä sekventiaalisesti vierusparin etujäsenenä tai opettajan johdattelun tuloksena myös jälkijäsenenä (ks. myös Tanner, 2012). Pyyntöön voidaan reagoida hyväksyen, kieltäen (esim. Tainio, 1997) tai luvaten (ks. suspension turn, Keisanen, Rauniomaa \& Haddington, 2014; ks. myös Rauniomaa \& Keisanen, 2012).

Tutkimuksen analyysiä sävyttää opettajan kaksoisrooli opetuksen toteuttajana ja tutkijana. Vaikka opettaja ei tietoisesti kehitä opetustaan (ks. Heikkinen, Rovio \& Syrjälä, 2007), voidaan tätä etnografisiin havain- 


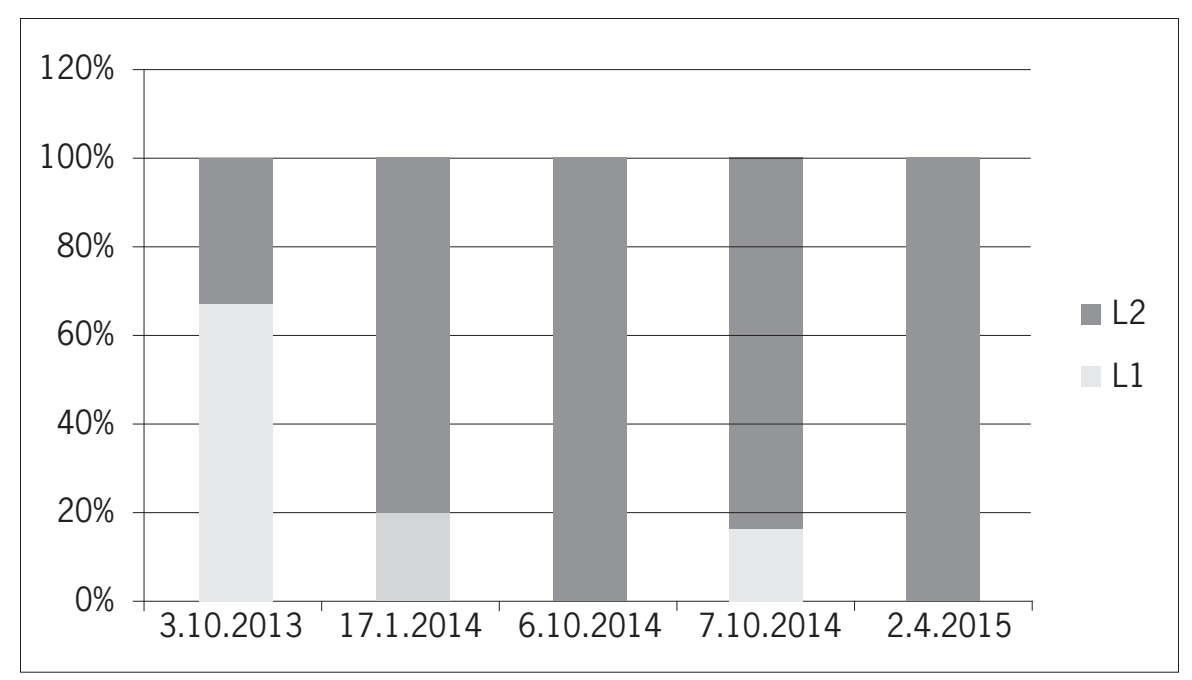

KUVIO 1. Äidinkielisten (L1) ja kohdekielisten (L2) pyyntörakenteiden jakautuminen.

toihin pohjautuvaa tutkimusta luonnehtia myös joiltain osin toimintatutkimukseksi. Tutkimuksen reliabiliteetin vahvistamiseksi litteraatit on lukenut syntyperäinen kielenpuhuja, joka on myös kommentoinut niissä esiintyviä pyyntöjä.

\section{KOHDEKIELI KORVAA ENSIKIELEN, JA RAKENTEET MONIMUOTOISTUVAT}

\subsection{Pyynnöt muuttuvat venäjänkielisiksi}

Kuviosta käy ilmi, että oppilaiden aloittamat pyynnöt muuttuvat jo ensimmäisen alkuopetusvuoden aikana lähes täysin kohdekielisiksi.

Ensimmäisessä alkuvaiheen sekvenssissä (3.10.2013) on havaittavissa, että oppilaat muodostavat pyyntöjä enemmän suomeksi kuin venäjäksi (67\%). Jo toisessa alkuvaiheen jaksossa (17.1.2014) esiintyy enää kaksi suomenkielistä pyyntöä. Toisen luokan alussa (6.10. ja 7.10.2014) venäjänkielisiä pyyntöjä käytetään runsaasti, mutta joukossa on vielä muutama suomenkielinenkin. Niin ikään loppuvaiheen viimeisessä sekvenssissä (2.4.2015) pyynnöt ilmaistaan jo täysin koh- dekielisinä. On todettava, että aineistossa esiintyy muutamia yksittäisiä oppilaan tuottamia pyyntöjä, joihin ei liity kielellistä responssia eli jälkijäsentä. Näitä ei ole laskettu analysoitaviksi pyyntösekvensseiksi. Tämä ei kuitenkaan muuta sitä tilannetta, että suomeksi oppilaat eivät pyyntöjä juuri enää esitä.

Seuraavien kolmen esimerkin (esimerkit 1-3) avulla tarkastelen tarkemmin pyyntöjen muuttumisprosessia suomenkielisistä venäjänkielisiksi. Ensimmäinen alkuvaiheeseen sijoittuva esimerkki osoittaa kielisopimuksen draamallisuuden. Minttu esittää suomen kielellä pyynnöksi tulkittavan lausuman, johon opettaja reagoi kielteisesti, jopa tylysti, muistuttaen tällä tavalla kielisopimuksesta. Seuraavassa vaiheessa kuvataan tilannetta, jossa Nea on jo "oppinut tavoille" pyytäessään tarvitsemaansa tussia käyttäen hänelle mallinnettua rakennekehystä možno (saako) ja sijoittaen siihen pyyntönsä kohteen. Tässä tilanteessa opettaja hyväksyy välittömästi oppilaan venäjänkielisen pyynnön. Kolmas aineistoesimerkki kertoo jo kielisopimuksen oppimisesta. Akseli aloittaa pyyntönsä suomeksi, mutta havaitsee pian, että tähän ei reagoida. Kun hän ilmaisee oma-aloitteisesti epä- 
suoran pyyntönsä venäjäksi, palvelu toimii.

Ensimmäinen esimerkki on tilanteesta, jossa oppilasryhmää ohjaamassa on kaksi opettajaa (T1 ja T2). He jakavat muovailuvahaa, jota oppilaat työskentelyssään tarvitsevat.
Minttu tulee opettajan (T1) viereen, nostaa katseensa häneen ja pyytää suomeksi vihreää muovailuvahaa (r.1) käyttäen kysymysmuotoista rakennetta (ks. Tanner, 2012).

Esimerkki 1 (3.10. 2013) [onks tääl vihreetä?]

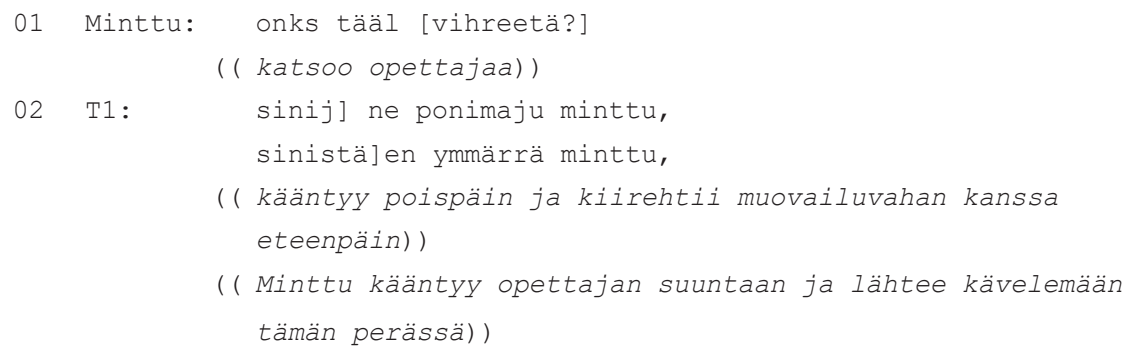

Opettaja vastaa osittain Mintun kanssa päällekkäispuhuntana ensin toiselle oppilaalle sinistä samalla kääntyen Mintusta pois ja jatkaen matkaansa muualle (r. 2). Minttu kääntyy niin ikään opettajan suuntaan ja kävelee tämän perässä. Opettaja hylkää pyynnön tylysti muistuttaen epäsuorasti kielisopimuksesta lausumalla en ymmärrä minttu. Minttu lähtee seuraamaan opettajaa. Myöhemmin videolta kuitenkin näkyy, miten Minttu hyppelee iloisena muovailuvahaa kädessään.

Opettaja valehtelee väittäessään, että ei ymmärrä Mintun pyyntöä. Opettajan kaksoisrooli oppilaiden ensikielen osaajana ja toisaalta kohdekielen syöttäjänä on kuitenkin osa luokkayhteisön toimintakulttuuria ja hänen pedagogista osaamistaan (Seidlhofer, 1999). Vaikka opettajan käytös saattaisi ulkopuolisin silmin vaikuttaa tylyltä, Minttu tietää tämän ymmärtäneen hänen suomenkielisen pyyntönsä. Lähteminen opettajan perään antaa Mintulle lisäaikaa monitoroida tilannetta ja ylläpitää toivetta saada haluamaansa materiaalia.

Toisessa esimerkissä Nea tulee opettajan viereen ja pyytää venäjäksi mustan tussin. Vuoronvaihto käynnistyy Nean puhutellessa opettajaa etunimellä. Tämän jälkeen hän aloittaa pyyntönsä käyttämällä aiemmin opettajan mallintamaa rakennekehystä, joka alkaa modaalissävytteisellä adverbilla saako mustan tussin (r. 1) (esim. Bolden, 2017; Yli-Piipari, 2002).

Esimerkki 2 (17.1.2014) [saako mustan tussin?]

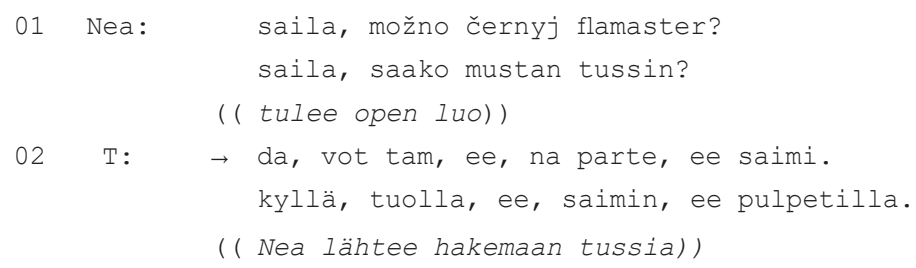


Nea pyytää venäjäksi mustaa tussia možnorakennekehyksen avulla (r.1). Opettaja reagoi pyyntöön hyväksymällä sen välittömästi (r.2). Opettajan empimisääntely ee osoittaa lievää epäröintiä, mutta hän antaa Nealle epäsuorasti luvan hakea mustan tussin itse kertomalla sen olevan Saimin pulpetilla. Venäjäksi esitetystä pyynnöstä seuraa siis heti sen hyväksyminen.
Kolmannessa esimerkissä on meneillään tilanne, jossa Akseli on juuri pyytänyt Sailaopettajalta vanua. Myös muita oppilaita on samaan aikaan opettajan vierellä, ja tämä puhuu välillä myös heille. Akseli muodostaa epäsuorasti suomenkielisen pyynnön, jonka hän esittää väitelauseen muotoisena. Pyyntö implikoi sitä, että vanua tarvitaankin paljon.

Esimerkki $3(7.10 .2014)$ [mul on aika iso]

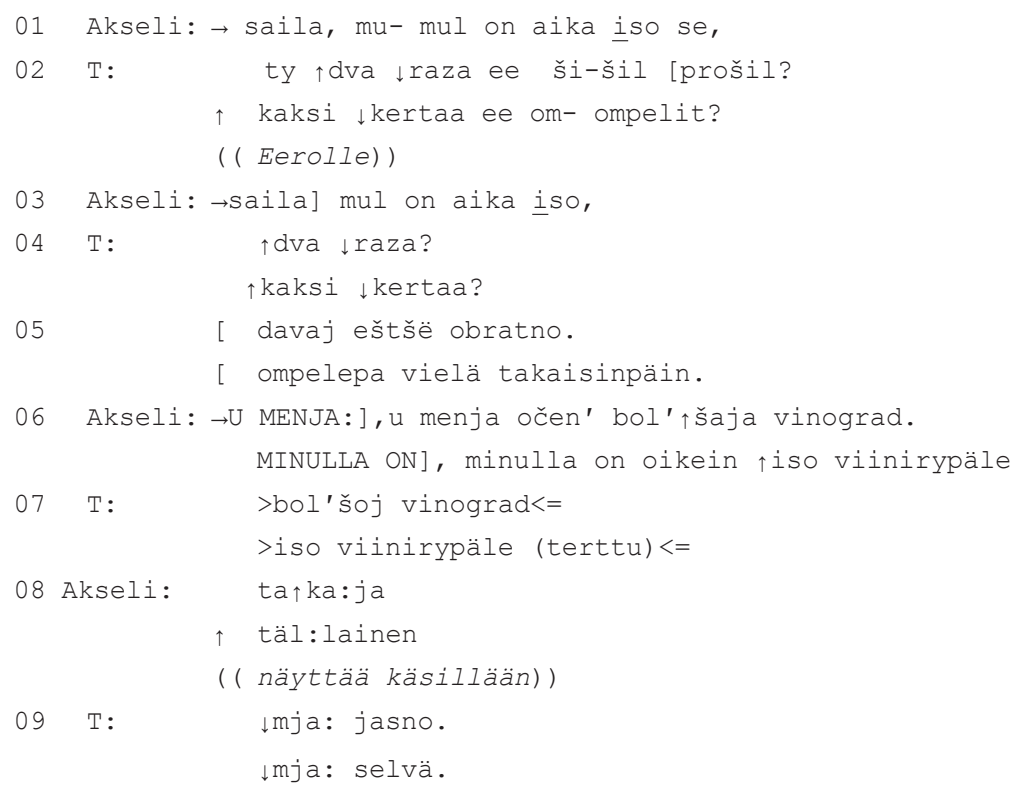

Akseli puhuttelee opettajaa etunimeltä ja muotoilee väitelauseen mul on aika iso lopettavaan adjektiiviin lisämerkityksen käyttämällä epäkonventionaalista lausepainoa (r. 1) Opettaja ei heti kuule Akselin suomenkielistä vihjailua (tai ei reagoi siihen), vaan tiedustelee vieressään olevalta Eerolta, onko tämä ommellut kahteen kertaan tietyn kohdan ompelutyössään (r. 2). Osittain opettajan lausuman (r. 2) kanssa päällekkäin Akseli toistaa suomenkielisen pyyntönsä aloittaen sen taas puhuttelemalla opettajaa ja toistaen suomeksi, että työ on aika iso (r. 3). Kun opettaja ei vieläkään reagoi, vaan jatkaa Eeron neuvomista (r. 4-5) Akseli korottaa ääntään ja vaihtaa kielen venäjäksi. Akseli myös lausuu adjektiivin iso nostaen sanan kohdalla sävelkorkeutta. Akselin kohdekielinen vastine motivoituu oletettavasti opettajan käytöksestä vuoronvaihdon alussa. Opettaja suuntautuu välittömästi Akselin venäjänkieliseen pyyntöön. Hän toistaa nopeahkossa tempossa Akselin muodostamasta lausumasta olennaisen, suuri viinirypäle (tert$t u)$, samalla korjaten adjektiivin maskuliiniseen muotoon (r. 7). Akseli vahvistaa vielä pyyntönsä venyttäen pronominia tällainen. Samalla hän nostaa sanan sävelkorkeutta ja 
täydentää ilmaisuaan eleellä, jota hän käyttää korostamaan käsityönsä suuruutta (r. 8). Akselin viesti, pyyntö saada paljon vanua, on oletettavasti mennyt perille. Opettaja tuottaa vielä partikkelin mjaa hieman pidentäen sitä ja lisää perään toisen partikkelin selvä ilmaisten näin kuitanneensa pyynnön (r. 9). Myöhemmin videolta on nähtävissä Akselin tyytyväinen ilme hänen kävellessään omalle paikalleen vanua kädessään.

Yllä esitellyssä esimerkissä Akseli yrittää kääntää venäjäksi, mitä on aikaisemmin sanonut suomeksi, ja pääsee siten tavoitteeseensa (r. 6). Adjektiivi iso purkautuu tässä kontekstissa vihjeeksi tarvitsen paljon vanua. Voidaankin sanoa, että Akseli tekee väitelauseesta pyyntörakenteen epätyypillisen prosodisen indeksin avulla liittäen siihen myös toimintoa vahvistavan eleen.

Kielisopimuksen oppiminen on mielestäni osoitus lähinnä siitä, millaista sosiaalista voimaa on oppilaiden tuottamissa venäjänkielisissä pyynnöissä. Vuorovaikutuksessahan sekä pyynnön esittäjän että sen vastaanottajan yhteinen sitoutuminen on keskeistä (ks. Enfield, 2014 ja Lauranto, 2015). Ensimmäisen kouluvuoden alussa oppilaat käyttivät opettajan luona asioidessaan vielä paljon suomenkielisiä ilmauksia halutessaan materiaalia, palvelua tai huomiota (vrt. Tanner, 2012). Osallistuminen oli silloin vielä mo- nen kohdalla perifeeristä (Lave \& Wenger, 1991; ks. myös Enfield, 2014 ja Lauranto, 2015) eikä pyyntöjä hyväksytty ainakaan suoraan. Täysivaltaisen osallistumisen mahdollisti siirtyminen luokan toimintakulttuurissa hyväksytymmän kohdekielen käyttöön.

\subsection{Imperativirakenteinen pyyntö saavuttaa jalansijaa}

Tässä tutkimuksessa pyyntöä tarkastellaan myös rakenteena tai osana rakennekehystä (Kauppinen, 1989; Tanner, 2012; Wong-Fillmore, 1979). Opettaja toteuttaa CLIL-luokassaan toiminnan kielentäjän rooliaan (Savijärvi, 2011) lähes kaikissa asiointitilanteissa, joissa oppilaat ilmaisevat pyyntöjään. Suurin osa oppilaiden tuottamista pyynnöistä esiintyy vierusparin etujäsenenä, johon opettaja jälkijäsenessään fyysisesti ja kielellisesti reagoi. Tanneria (2012) mukaillen olen luokitellut oppilaiden esittämiä pyyntöjä rakenteellisesti (Taulukko 1). Tannerin luokittelu soveltuu analyysiini, koska alkuvaiheessa oppilaat esittävät pyyntöjä suurimmaksi osaksi suomeksi. Venäjänkieliset možno -rakennekehyksellä ilmaistut pyynnöt luokittelen kysyviksi, vaikka niistä puuttuisi kysymykselle ominainen intonaatio (ks. esim. Ojanen, 1972; RG, 1980, \$153) Antakaa olkaa hyvä-rakennekehykset ovat luonnollisesti käskyjä.

TAULUKKO 1. Pyyntöjen rakenteellinen luokittelu.

\begin{tabular}{|l|r|r|r|r|r|r|}
\hline Rakenne & $\mathbf{3 . 1 0 . 2 0 1 3}$ & $\mathbf{1 7 . 1 . 2 0 1 4}$ & $\mathbf{6 . 1 0 . 2 0 1 4}$ & $\mathbf{7 . 1 0 . 2 0 1 4}$ & $\mathbf{2 . 4 . 2 0 1 5}$ & yht. \\
\hline kysyvät & 5 & 7 & 2 & 5 & 4 & $\mathbf{2 3}$ \\
\hline väitteet & 10 & 1 & 3 & 5 & 0 & 19 \\
\hline käskyt & 1 & 2 & 1 & 21 & 6 & $\mathbf{3 1}$ \\
\hline nominilausekkeet & 6 & 0 & 3 & 2 & 1 & 12 \\
\hline Yhteensä & 24 & 10 & $\mathbf{9}$ & $\mathbf{3 1}$ & $\mathbf{1 1}$ & $\mathbf{8 5}$ \\
\hline
\end{tabular}


Vaikka suomenkieliset (myönteiset tai kielteiset) väitelauseen muotoiset pyyntörakenteet olivat erityisesti alkuvaiheen ilmiö (esimerkki 4), niitä esiintyi jonkin verran myös loppuvaiheessa (esimerkki 3). Seuraava esimerkki kuvaa melko tyypillistä alkuvaiheen vuorovaikutusta, jossa oppilaat esittävät pyyntönsä useimmiten suomeksi. Myös kovaääninen juttelu suomeksi on yleistä. Meluisaa askartelutuntia vedetään kahden opettajan ( $\mathrm{T} 1$ ja T2) voimin. Molemmat ovat kiireisiä jakaessaan muovailuvahaa ja auttaessaan oppilaita. Saimi istuu luokan takana ryhmässä, jossa istuvat myös Niki, Niko ja Väinö. Opettaja on juuri tullut kyseisen ryhmän luo jakamaan muovailuvahaa.

Esimerkki 4 (3.10.2013) [MULLA EI OO SINISTÄ]

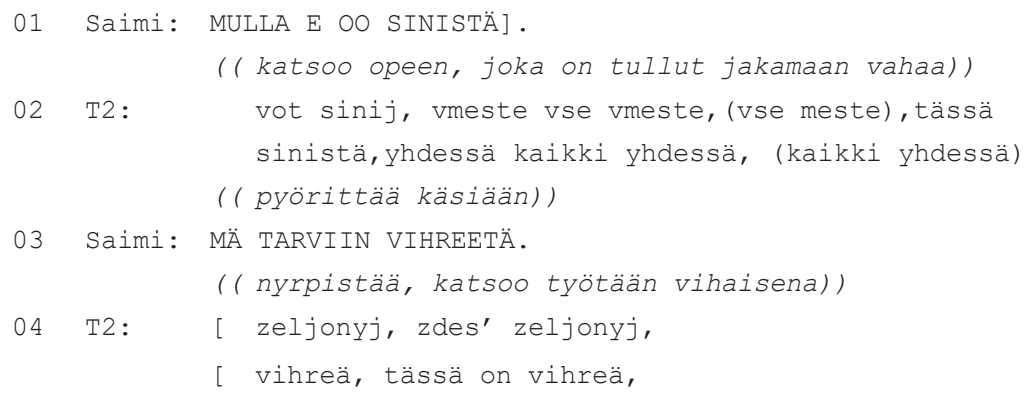

Rekisteröityään opettajan ilmoituksen mahdollisesti tarjolla olevasta sinisestä muovailuvahasta Saimi tuottaa suomenkielisen, kielteisen väitelauseen muotoisen lausuman kovalla äänellä (r. 1). Kielisopimuksen vastaisesti opettaja (T2) hyväksyy Saimin suomenkielisen pyynnöksi tulkittavan ilmauksen. Hän täyttää Saimin pyynnön ojentamalla sinisen muovailuvahan ja ilmoittaa samalla, että vaha on tarkoitettu koko ryhmälle (r. 2). Opettaja vahvistaa jälkijäsentään kaikki yhdessä pyörittämällä samalla käsiään. Saimi jatkaa suomeksi tyytymättömyyden osoitustaan nyrpistäen nenäänsä ja julistaen ympäristöä voimakkaammalla äänellä, että hän tarvitsee myös vihreää (r. 3). Tämänkin, väitteen muotoisen ja myös epäkohteliaan, pyynnön opettaja hyväksyy välittömästi tarjoamalla Saimille vihreää vahaa samalla kielellisesti vahvistaen kaksi kertaa vahan olevan vaaditun väristä (r. 4). Saimi ei siis malta odottaa, että hänelle joko tarjottaisiin vahaa tai hän voisi kohteliaasti sitä pyytää opettajan tullessa lähelle. Lisäksi hän vahvistaa affektia prosodisin keinoin, korottamalla ääntään. Voidaan myös ajatella, että opettajan (T2) kielisopimuksen vastainen toiminta hämmentää Saimia. Kovaääninen suomenkielinen ilmaus saakin aikaan oppilaalle mieluista toimintaa pyyntö hyväksytään.

Alkuvaiheessa esiintyi muutama nominilausekkeella eli ilman finiittiverbiä ilmaistu suomenkielinen pyyntö. Tosin kaksi oppilasta tuotti huomiota hakevan pyynnön pelkällä venäjänkielisellä adjektiivilla. Seuraava esimerkki kuvaa askartelutuntia, jonka aikana oppilaat ovat yrittäneet sekoittaa vihreää muovailuvahaa keltaisesta ja sinisestä. Niilo onnistuu viimein ja haluaa esitellä aikaansaannostaan opettajalle. 
Esimerkki 5 (3.10.2013) [vihreää]

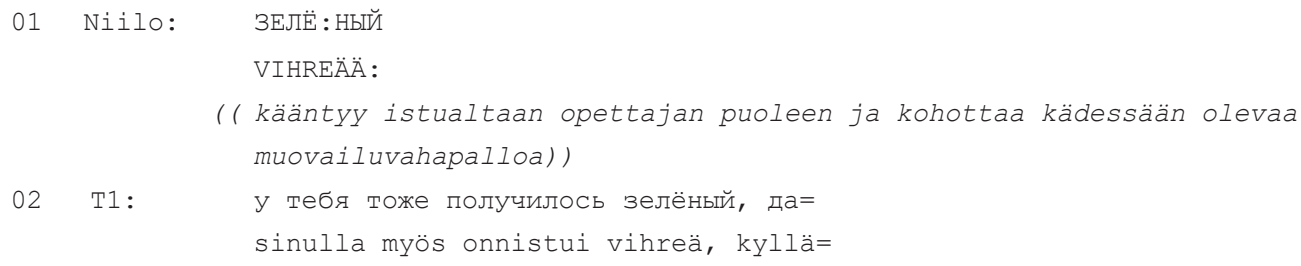

Rivillä yksi Niilo lausuu adjektiivin vihreä ympäristöä voimakkaammalla äänellä. Samalla hän kääntyy paikallaan istuen opettajaan päin ja kohottaa vihreää ja pallonmuotoista muovailuvahaa tätä kohti. Opettaja hyväksyy heti Niilon huomiota hakevan pyynnön kielentäen samalla tämän toimintaa pidemmällä virkkeellä (r. 2).

Opettaja on ensimmäisen luokan alussa mallintanut oppilaille helpohkon saako-rakenteen (ks. esimerkki 2). Kielitaidon karttuessa hän yrittää laajentaa oppilaiden pyyntörepertuaaria jo hieman monimutkaisemmalla, mutta venäjän kielessä yleisemmin käytetyllä ja myös kohteliaalla imperatiivimuotoisella rakennekehyksellä (ks. Bolden, 2017; Wong-Fillmore, 1979) Antakaa, olkaa byvä (ks. esimerkki 7). Saako-rakennekehyksiä esiintyy aineistossa koko ajan, ja suurimman osan niistä opettaja hyväksyykin sellaisenaan jälkijäsenessään. Loppuvaiheessa (erityisesti
6.10.2014-2.4.2015 sekvensseissä) saako-rakennekehyksen syrjäyttää kuitenkin useaan kertaan mallinnettu imperatiivirakenteinen pyyntö.

Seuraavaksi esittelen tarkemmin venäjän kielellä ilmaistun imperatiivimuotoisen pyyntörakenteen syntyvaiheita CLIL-luokassani. Havainnollistan tätä ilmiötä Saimin ja Sadun tuottamien pyyntöjen tarkastelun kautta (esimerkit 6-7), vaikka myös monen muun oppilaan pyytämiskäytänteissä tapahtuu vastaava muutos. Satu on ollut alusta lähtien aktiivinen venäjän kielen käyttäjä näissä oppilaskeskeisissä aktiviteeteissa ja ehkä siitä syystä opettaja näkee mahdolliseksi vaatia häneltä jo astetta parempaa kohdekielen tuotosta (esimerkki 6) aikaisemmin kuin esimerkiksi Saimilta (vrt. esimerkki 4).

Satu on kiiruhtanut luokan takaosasta opettajan viereen luokan etuosaan pyytämään neulaa.

Esimerkki 6 (6.10.2014) [saako?]

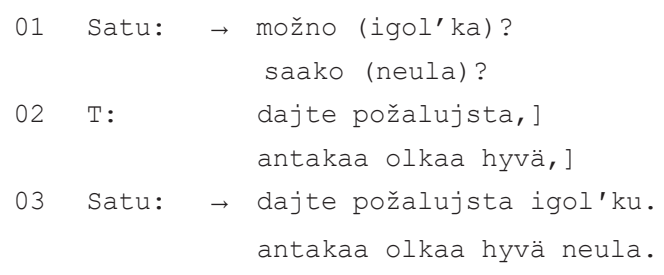


Satu aloittaa pyytämisen modaalisella saako-adverbilla (r. 1). Hän sijoittaa tähän tutumpaan rakennekehykseen pyynnön kohteen neula nominatiivimuodossa. Opettaja reagoi Sadun lausumaan mallintaen hänelle imperatiivimuotoisen rakennekehyksen antakaa olkaa hyvä (r. 2) käyttäen tasaista intonaatiota. Rivillä kolme Satu toistaa opettajan antaman alun ja sijoittaa siihenkin pyynnön kohteen neula tällä kertaa oikeassa akkusatiivimuodossa. Opettaja antaa tällä tavalla Sadulle kielellisiä aineksia kohteliaamman pyynnön tuottamiseen tekemällä eksplisiittisen korjauksen. Opettajan käyttämä tasainen intonaatio indikoi sitä, että hän odottaa Sadun jatkavan tästä itse. Tässä esimerkissä on kaksi pyynnön sisältävää vuoronvaihtoa: Ensimmäisessä saako-alkuinen pyyntörakenne on sekventi-

Esimerkki 7 (7.10.2014) [antakaa olkaa hyvä vanua]

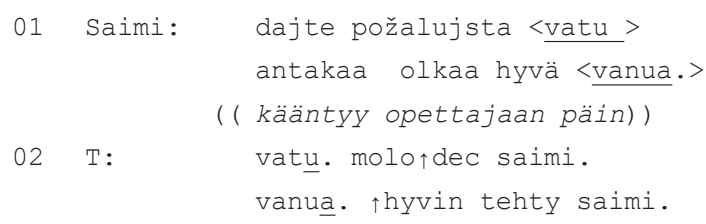

Saimi tuottaa imperatiivirakenteisen kohteliaisuussanalla varustetun pyynnön painottaen substantiivin vanua u-loppuista akkusatiivin päätettä. Hän myös hidastaa lausumansa loppua (r. 1). Kohdistaessaan pyyntönsä opettajalle Saimi kääntyy tähän päin ja katsoo kohti. Opettaja reagoi välittömästi Saimin venäjänkieliseen pyyntöön toistamalla sekä painottaen pyynnön kohteen oikeata akkusatiivin päätettä $u$, vanua (r. 2). Opettaja myös kehuu Saimia merkiten prosodisesti substantiivin muotoisen hyvin tehty (venäjässä substantiivi molodec voidaan kääntää useilla eri tavoilla, esimerkiksi hyvä, hyvin tehty, oletpa taitava). Tilanne jatkuu (ei näy esimerkissä) aalisesti etujäsen ja toisessa (r. 3) opettajan johdattelusta motivoitunut jälkijäsen. Kohteliaisuussana olkaa hyvä imperatiivimuotoisen rakennekehyksen yhteydessä ohjaa vuoronvaihtoa kohti institutionaalista tavoitetta eli suositeltavaa kohdekielistä pyytämisen rakennetta.

Toisin kuin ensimmäisenä luokan syksyllä (esimerkki 4), Saimi osoittaa toisen luokan alkuvaiheessa jo sopeutuneensa luokkayhteisön käytänteisiin. Tämä näkyy seuraavassa esimerkissä hänen tavastaan muotoilla pyyntönsä opettajan antaman mallin mukaiseksi (esimerkki 7). Käsityötunnin alussa järjestäjät jakavat käsityölaatikoita. Opettaja on juuri kertonut näyttävänsä, miten ompelutyö päätellään. Saimi on saanut oman käsityölaatikkonsa ja pyytää kohteliaasti vanua ensimmäisenä omalta paikaltaan. niin, että opettaja kiikuttaa itse vanun suoraan Saimin eteen tämän pulpetille.

Kysymyksessä on pyyntörakenne, joka sekventiaalisesti toimii oppilaan tuottamana etujäsenenä. Tätä seuraa opettajan välitön, hyväksyvä jälkijäsenen sekä konkreettinen palkitseminen. Verrattuna alkuvaiheen affektiiviseen toimintaan Saimin käytös on muuttunut hillitymmäksi ja kohteliaammaksi. Kielisopimuksen lisäksi hän osoittaa myös hallitsevansa imperatiivisen pyynnön sisältävän rakennekehyksen sijoittamalla siihen omaa tuotosta. Akkusatiivin päätteen painottaminen kertoo siitä, että Saimi on hyvin tietoinen siitä, mitä häneltä oppilaana tässä luokkayhteisössä odo- 
tetaan: oikeaoppista pyyntörakenteen muotoilua ja muutakin kieliopillista tietämystä. Tämä viimeinen esimerkki valaisee yleisesti loppuvaiheen sekvensseille ominaista ilmiötä: imperatiivisen rakennekehyksen avulla tuotettuja pyyntöjä satelee opettajalle jopa siinä määrin, että niiden välitön hyväksyminen on jo mahdotonta.

Analyysin yhteenvetona voidaan todeta, että oppilaiden pyynnöt muuttuivat jo ensimmäisen vuoden keväällä suomenkielisistä lähes täysin venäjänkielisiksi. Tämä johtui todennäköisesti siitä, että ajan kuluessa oppilaat omaksuivat luokkayhteisön toimintakulttuuria muovanneen kielisopimuksen. Opettaja toimi ikään kuin kaksoisagenttina (Seidlhofer, 1999) altistaen oppilaat mahdollisimman suurelle kielisyötteelle ja sen haltuun ottamiselle silti jättämättä heitä oman onnensa nojaan selviytymään tilanteesta. Aluksi oppilaat tuottivat pyyntöjä pääosin suomenkielisinä väite- ja kysymyslauseina. Pyyntöjen kohteena oli usein huomion tai palvelun saaminen, joskus myös materiaali. Vaikka tutkimus fokusoitui oppilaan esittämiin pyyntöihin, oli opettajan ilmauksilla niitä ennen ja niiden jälkeen vaikutusta pyynnön sisältävien vuoronvaihtojaksojen muodostumiseen. Vähitellen oppilaat siirtyivätkin käyttämään heille mallinnettuja venäjänkielisiä pyyntöjä lähinnä kahdella tavalla: Aluksisaako (možno)-rakenteella ja myöhemmin imperatiivimuotoisella rakennekehyksellä. Ilmeistä oli myös se, että opettajan tarjoamat mallit toimivat kehyksenä (esim. Kauppinen, 1989; Wong-Fillmore, 1979), jonka avulla oppilaat kykenivät lopulta produktiivisempaan pyyntöjen muotoiluun. Erityisesti tämän imperatiivimuotoisen pyyntörakenteen käyttö kohteliaisuussanan olkaa byvä (požalujsta) kera lisääntyi siinä määrin, että siitä muodostui selvästi osallistumisen tapa tämäntyyppisissä aktiviteeteissa.

\section{PYYNTÖRAKENTEILLA OPPIVAN YHTEISÖN JÄSENEKSI}

Tämän tapaustutkimuksen tarkoituksena oli tarkastella oppilaiden tuottamien pyyntörakenteiden käyttöä ja kehitystä venäjänkielisessä CLIL-alkuopetuksessa kahden vuoden aikana. Tutkimus osoitti, että jo hyvin varhain ns. asioimisen kieleksi luokassa muodostui kohdekieli, venäjä. Venäjänkielisten pyyntöjen lisääntyminen johtui todennäköisesti kielisopimuksen oppimisesta. Oppilaat tekivät runsaasti aloitteita pienelläkin venäjän kielen taidolla pyytäen tarvitsemaansa materiaalia, huomiota tai lupaa tehdä haluamiaan asioita.

Wong-Fillmoren (1979) tutkimuksessa havaittiin, että niukkaa kielitaitoa voi kompensoida sosiaalisilla resursseilla. Tämä teesi toimii myös toisinpäin: rakennekehyksillä voidaan luovia sosiaalisessa kanssakäymisessä. Tilanteisen oppimisen teoria (Lave \& Wenger, 1991) tukee analyysiä CLIL-luokan oppilaiden osallistamisesta. Erityisen hyvin tämä näkökulma sopi pitkittäisaineiston tarkasteluun, koska silloin voidaan nähdä oppijan kehittyminen periferiasta täysivaltaiseen osallistumiseen. Tässä työssä osallistuminen legitimoitiin pyyntörakenteilla, joita harjoiteltiin osaavampien kanssa autenttisissa ja muuttuvissa tilanteissa matkimalla ja tekemällä (ks. Lave \& Wenger, 1991; Savijärvi, 2011). Aluksi riitti suomenkielinen väitteen tai kysymyksen muotoinen rakenne, mutta myöhemmin vaadittiin venäjänkielistä ja korrektimpaa kielenkäyttöä. Myös sosiokulttuuriset oppimisen teoriat painottavat sellaista sosiaalista vuorovaikutusta, jossa tärkeässä roolissa on taitavampi asiantuntija. Oppilas voi hänelle mallinnetun pyyntörakenteen avulla hakeutua vuorovaikutukseen. Ratkaisevaa on kuitenkin se, miten oppilaan aloittamaan pyyntöön reagoidaan. Voidaankin ajatella, että oppijalle merkityksellisen kielenkäyttötilanteen järjestäminen ei vielä riitä. Lisäksi tarvitaan 
jatkuvaa asiantuntijapalautetta siitä, miten esimerkiksi pyyntö kielellisesti esitetään.

Oppilaan prioriteetteihin tuskin kuuluu käydä keskustelua kohdekielellä, jos hän on tullut pyytämään vain vanua tai lankaa. Tärkeätä olisi kuitenkin pohtia, mitä tapahtuu oppilaiden kehittyvälle kielitaidolle, jos heidän aloitteisiinsa ei kielellisesti tartuta. Luonnollisestikaan kieli ei kehity, jos pyyntö vain niukasti hyväksytään tai hylätään. Pyyntöön reagoiminen niin, että sen esittäjä saa tukea, vaatii opettajalta nopeutta reagoida. Tukimuotojen on oltava myös sellaisia, joita oppilas voi hyödyntää lähikehityksensä vyöhykkeellä. Opettajan tai taitavamman vertaisoppijan tarjoama oikea-aikainen tuki (scaffolding) tarjoaa hyvän työkalun, jolla lähikehityksen vyöhykettä voidaan rakentaa (esim. Donato, 1994; Sharpe, 2006). Hyvä jatkotutkimuksen kohde olisikin tarkastella tätä lähivuorovaikutuksen yhteydessä tarjolla olevaa tukea tarkemmin.

Pyyntöjä voisi tarkastella myös siitä näkökulmasta, miten ne tukevat osallistumista ylipäätään. Kielellisiä pyyntöjä esitti noin puolet oppilaista. Tosin tämä ei välttämättä kerro muiden oppilaiden passiivisuudesta eikä kielellisestä tai sosiaalisesta taitamattomuudesta. Tuntiaktiviteetin luonne yksinkertaisesti oli sellainen, että se salli hyvin itsenäisen työskentelyn. Toisaalta osa oppilaista saattoi halutessaan vain esitellä työtään opettajalle tai avustajalle huomiota hakevalla pyynnöllä. Näin ollen aktiviteetti antoi oppilaille mahdollisuuden ilmaista itseään niin taidollisesti ja tiedollisesti kuin sosiaalisestikin.

Jatkotutkimusta olisi erittäin aiheellista tehdä myös ulkopuolisen tarkkailijan silmin. Huolimatta siitä, että tutkimus pohjautuu täysin empiiriseen aineistoon, omia kielimallejaan nauhoittava ja tutkiva opettaja yhteisönsä täysivaltaisena osallistujana saattaa myös muuttaa tiedostamattaan sosiaalista todellisuutta. Tutkiva opettaja pyrittiin kuiten- kin etäännyttämään osallistuvasta opettajasta siten, että aineisto litteroitiin yksityiskohtaisesti. Niinikään aitoja keskusteluja tarkasteleva keskustelunanalyysi menetelmänä ei pohjaa etukäteisluokitteluihin. Kielisopimuksen käyttöönoton, kuten ei myöskään kielellisiin rakennemalleihin painottuneen CLIL-opetuksen vaikutuksista ollut aineiston keruun alkaessa vielä tietoa. Nauhoitusten aikana eivät myöskään tutkimuskysymykset olleet vielä muotoutuneet. Lisätietoa yhteisöllisyyden ja osallistumisen rakentumisesta olisi saatu tutkimalla aineistosta myös kehollista viestintää multimodaalisesti (ks. esim. Kääntä \& Haddington, 2011). Tämän tarkasteluun ei yhdellä kameralla kuvattu aineisto kuitenkaan riittänyt.

Tutkimukseni osoittaa, että venäjänkielisessä CLIL-opetuksessa voidaan omaksua itse sisällön lisäksi myös kielen rakenteita, sanastoa ja pragmatiikkaa. Vieraan kielen oppimista tapahtuu silloin ikään kuin huomaamatta oppilaita osallistavan toiminnan ohessa. Kieli on kuitenkin tehtävä näkyväksi (esim. Nikula, 2015) ja oppilaille on luotava autenttisia eli heille merkityksellisiä kielenkäyttötilanteita (POPS2014/luku 10). Huolimatta siitä, että opetussuunnitelman perusteissa (POPS2014) oppija määritellään aktiiviseksi toimijaksi, opettajan rooli nousee tärkeäksi kohdekielisen vuorovaikutuksen ohjaajana. CLIL-opetuksessa osallistujien välisellä kielisopimuksella opettaja voi ohjata toimijuutta oikeaan suuntaan.

Tutkimukseni on myös syytä asettaa laajempaan kontekstiin kielipoliittisena kannanottona. Suomessa opiskellaan venäjää edelleen erittäin vähän. Useista yrityksistä huolimatta A-venäjän opiskelijoiden määrää ei ole pystytty lisäämään (Mustaparta, 2001). Mustajoen ja Protasovan (2010, s. 6) mukaan Suomen kielipolitiikka on ristiriitaista: monikielisyyden perään kuulutetaan, mutta käytännössä suomalaisten kielitaito kapenee. Kielen ope- 
tuksen autentisoimisella, jota tutkimukseni myöskin edustaa, voidaan luoda uudenlaista kiinnostusta itse kieltä ja kulttuuria kohtaan.

\section{LÄHTEET}

Bolden, G. (2017). Requests for here-and-now actions in Russian conversation. Teoksessa M.L. Sorjonen, L. Raevaara \& E. Couper-Kuhlen (toim.), Imperative turns-at-talk: The design of conversational directives (s. 175-212). Amsterdam, Philadelphia: John Benjamins.

Dalton-Puffer, C. (2007). Discourse in Content and Language Integrated Learning (CLIL) classrooms. Language Learning \& Language Teaching, 20. Amsterdam, Philadelphia: John Benjamins.

Dalton-Puffer, C. \& Nikula, T. (2006). Pragmatics of content-based instruction: Teacher and student directives in Finnish and Austrian classrooms. Applied Linquistics, 27, 241-267.

Dalton-Puffer, C. \& Smit, U. (2013). Content and language integrated learning: A research agenda. Language Teaching, 46, 545-559.

Donato, R. (1994). Collective scaffolding in second language learning. Teoksessa P. Lantolf \& G. Appel (toim.). Vygotskyan approaches to second language research (s. 33-56). Norwood, New Jersey: Ablex Publishing Corporation.

Drew, P. \& Couper-Kuhlen, E. (2014). Requesting - from speech act to recruitment. Teoksessa P. Drew \& E. Couper-Kuhlen (toim.), Requesting in social interaction. Studies in language and social interaction, SLSI 26 (s. 1-34). Amsterdam, Philadelphia: John Benjamins.

Enfield, N.J. (2014). Human agency and the infrastructure for requests. Teoksessa P. Drew \& E. Couper-Kuhlen (toim.), Requesting in social interaction (s. 35-54). Amsterdam, Philadelphia: John Benjamins.

Harklau, L. (2011). Approaches and methods in recent qualitative research. Teoksessa E. Hinkel (toim.), Handbook of research in second language teaching and learning (s. 175-189). New York, London: Routledge.

Heikkinen, H, L. T., Rovio, E. \& Syrjälä, L. (toim.) (2007). Toiminnasta tietoon. Toimintatutkimuksen menetelmät ja lähestymistavat. Helsinki: Kansanvalistusseura.
Jakonen, T. (2015). Handling knowledge: Using classroom materials to construct and interpret information requests. Journal of Pragmatics, 89 , $100-112$.

Jurkov, E.E., Protasova, E.J., Popova, T.I. \& Nikunlassi, A. (toim.) (2012). Formirovanie i ocenka kommunikativnoj kompetencii bilingvov $v$ processe dvujazyčhogo obrazovanija. SanktPeterburg: MIRS.

Kalliokoski, J., Mård-Miettinen, K. \& Nikula, T. (toim.) (2015). Kieli koulutuksen resurssina: vieraalla ja toisella kielellä oppimisen ja opetuksen näkökulmia. AFinLA-e: Soveltavan kielitieteen tutkimuksia, 8, 3-12.

Kauppinen, A. (1998). Puhekuviot, tilanteen ja rakenteen liitto. Tutkimus kielen omaksumisesta ja suomen konditionaalista. Helsinki: Suomalaisen Kirjallisuuden Seuran toimituksia 713.

Keisanen, T., Rauniomaa, M. \& Haddington, P. (2014). Suspending action. From simultaneous to consecutive ordering of multiple courses of action. Teoksessa P. Haddington, T. Keisanen, \& L. Mondada (toim.), Multiactivity in social interaction: Beyond multitasking (s. 109-136). Amsterdam, Philadelphia: John Benjamins.

Kuikka, E. (2001). Miten koululainen oppii venäjää Itä-Suomen suomalais-venäläisessä koulussa? Teoksessa K. Perho (toim.), Kahden kulttuurin väkeä. Suomalaiset ja venäläiset koulussa (s. 208-221). Joensuu: Joensuun yliopiston kasvatustieteellisen tiedekunnan selosteita, 82 . Kurhila, S. \& Laakso, M. (2016). Puhumisen haasteet. Teoksessa M. Stevanovic \& C. Lindholm (toim.), Keskustelunanalyysi. Kuinka tutkia sosiaalista toimintaa ja vuorovaikutusta (s. 224-242). Tampere: Vastapaino.

Kääntä, L. \& Haddington, P. (2011). Johdanto multimodaaliseen vuorovaikutukseen. Teoksessa P. Haddington \& L. Kääntä (toim.), Kieli, keho ja vuorovaikutus. Multimodaalinen näkökulma sosiaaliseen toimintaan (s. 11-45). Helsinki: Suomalaisen Kirjallisuuden seura.

Lantolf, James, P. \& Poehner, E. (2008). Introduction to sociocultural theory and the teaching of second languages. Teoksessa J. P. Lantolf \& M. E. Poehner (toim.), Sociocultural theory and the teaching of second languages (s. 1-30). London: Equinox Publishing Ltd.

Lantolf, J. P. \& Thorne, S.L. (2006). Sociocultural theory and the genesis of second language develop- 
ment. Oxford: Oxford University Press.

Lauranto, Y. (2015). Direktiivisyyden rajoja: Suomen kielen vaihtokauppasyntaksia. Väitöskirja. Helsingin yliopisto.

Lave, J. \& Wenger, E. (1991). Situated learning: Legitimateperipheral participation. Cambridge: Cambridge University Press.

Myles, F., Hooper, J. \& Mitchell, R. (1998). Rote or rule? Exploring the role of formulaic language in classroom foreign. Language Learning, 48, 323-263.

Markee, N. (2015). The overview of the conversation analysis tradition. Teoksessa N. Markee (toim.), The handbook of classroom discourse and interaction (s. 369-372). Oxford: Wiley Blackwell.

Mustajoki, A. (2006). Teorija funkcional'nogo sintaksisa. Ot semantičeskih struktur k jazykovym sredstvam. Moskova: Jazyki slavjanskoj kul'tury.

Mustajoki, A. \& Protasova, E. (2010). O russkom jazyke v Finljandii. Teoksessa Izučenie I prepodovanie russkogo jazyka v Finljandii. Cbornik statej (s. 4-12). Helsingin yliopisto: Zlatoust.

Mustaparta, A-K. (2001). Lisää autenttisuutta venäjän opiskeluun. Teoksessa K. Perho (toim.), Kahden kulttuurin väkeä. Suomalaiset ja venäläiset koulussa (s. 88-101). Joensuu: Joensuun yliopiston kasvatustieteellisen tiedekunnan selosteita 82.

Negueruela, E. (2008). Revolutionary pedagogies: Learning that leads (to) second language development. Teoksessa J. P. Lantolf \& P. Poehner (toim.), Sociocultural Theory and the Teaching of Second Languages (s. 189-227). London: Equinox Publishing Ltd.

Negueruela-Azarola, E., Garcia, P. N. \& Buescher, K. (2015). From Interaction to Intra-action. Teoksessa N. Markee (toim.), The handbook of classroom discourse and interaction (s. 233-249). Oxford: Wiley Blackwell.

Nikula, T. (2015). Hands-on tasks in CLIL science classrooms as sites for subject-specific language use and learning. System, 54, 14-27.

Nikula, T. \& Moore, P. (2016). Exploring translanguaging in CLIL. International Journal of Bilingual Education and Bilingualism, 1-13.

Ojanen, M. (1972). Opi venäjää 3. Kielioppi. Porvoo: WSOY.

Paukkeri, P. (2006). Recipient v russkom razgovore o raspredelenii funkcii meždu otvetami da, nu i tak. Väitöskirja. Helsingin yliopisto. Slavica Helsingensia, 28.

Pekarek Doehler, Simona, Wagner, Johannes \& González-Martínez, Esther (toim.) (2018). Longitudinal studies on the organization of social interaction (s. 3-36). Lontoo: Palgrave Macmillan.

POPS 2014. Perusopetuksen opetussuunnitelman perusteet. Helsinki: Opetushallitus.

Rauniomaa, M. \& Keisanen, T. 2012: Two multimodal formats for responding to requests. Journal of Pragmatics, 44, 829-842.

RG (Russkaja grammatika) (1980). Tom 1. Moskova: Izdatel' stvo Nauka.

Salehova, L.L. \& Grigor'jeva, K. S. (2016). Teorija social'nogo konstruktivizma kak osnova integracii inostrannogo jazyka i predtmetnogo soderžanija izučaemyh disciplin v tehničeskom vuze. Vestnik RUDN (Rossijskij universitet družby narodov), Serija Informatizacija obrazovanija, 2016, 1, 1-7. Saatavissa osoitteessa: https://cyberleninka.ru/article/v/teoriya-sotsialnogo-konstruktivizma-kak-osnova-integratsii-inostrannogoyazykai-predmetnogo-soderzhaniya-izuchaemyh-distsiplin-v

Savijärvi, M. (2011). Yhteisestä toiminnasta yhteiseen kieleen. Keskustelunanalyyttinen tutkimus toisen kielen oppimisesta kielikylpypäiväkodin arkitilanteissa. Väitöskirja. Helsingin yliopisto.

Schegloff, E. A. (2007). Sequence organization in interaction. A primer in conversation analysis. Cambridge: Cambridge University Press.

Sharpe, T. (2006). “Unpacking” scaffolding: Identifying discourse and multimodal strategies that support learning. Language and Education, 20, 211-231.

Seidlhofer, B. (1999). Double standards: Teacher education in the expanding circle. World Englishes, 18, 233-245.

Stevanovic, M. \& Lindholm, C. (toim.) (2016). Keskustelunanalyysi. Kuinka tutkia sosiaalista toimintaa ja vuorovaikutusta. Tampere: Vastapaino.

Tainio, L. (1997). Keskustelunanalyysin perusteet. Tampere: Vastapaino.

Tainio, L. (2007). Miten tutkia luokkahuoneen vuorovaikutusta keskustelunanalyysin keinoin? Teoksessa L. Tainio (toim.), Vuorovaikutusta luokkahuoneessa. Näkökulmana keskustelunanalyysi (s. 15ᄀ58). Helsinki: Helsingin yliopisto- 
paino.

Taleghani-Nikazm, C. \& Huth, T. (2010). L2 Requests: Preference-structure in talk-in-interaction. Multilingua. Journal of Cross-Cultural and Interlanguage Communication, 29 (2), 185-202.

Tanner, J. (2012). Rakenne, tilanne ja kohteliaisuus. Pyynnöt S2-oppikirjoissa ja autenttisissa keskusteluissa. Väitöskirja. Helsingin yliopisto.

Thorne, S. L. \& Hellermann, J. (2015). Sociocultural Approaches to Expert-novice Relationships in Second Language Interaction. Teoksessa N. Markee (toim.), The handbook of classroom discourse and interaction (s. 281-297). Oxford: Wiley Blackwell.
Yli-Piipari, M. (2002). Vyskazyvanija so značeniem pros'by i reakcii na nih v russkom i finskom jazykah. Lisensiaatintyö. Helsingin yliopisto.

Wong-Fillmore, L. (1979). Individual Differences in Second Language Acquisition. Teoksessa C. J. Fillmore, D. Kempler \& William, S-Y, Wang (toim.), Individual differences in language ability and language behavior (s. 203-228). New York: Academic Press.

Vygotsky, L. S. (1978). Mind in society: The development of higher psychological processes. USA: Library of Congress Cataloging in Publication Data.

Vygotsky, L. S. (1982). Ajattelu ja kieli. Espoo: Weilin \& Göös. 
LIITE 1. Litteroinnissa käytetyt merkit (Ks. Stevanovic \& Lindholm, 2016, s. 441):

$\begin{array}{ll}{[} & \text { päällekkäispuhunnan alku } \\ ] & \text { päallekkäispuhunnan loppu } \\ = & \text { kaksi lausumaa liittyy toisiinsa tauotta } \\ (0,5) & \text { hiljaisuus sekunteina } \\ (.) & 0,2 \text { sekuntia lyhyempi hiljaisuus } \\ \cdot & \text { laskeva sävelkulku } \\ , & \text { tasainen sävelkulku } \\ ? & \text { nouseva sävelkulku } \\ \text { sa- } & \text { sana jää kesken } \\ \text { sanna } & \text { sanan painottaminen } \\ \text { sa:na } & \text { äänteen venyttäminen } \\ \text { SANA } & \text { ympäröivää puhetta voimakkaammalla äänellä puhuttu jakso } \\ \text { osana } & \text { ympäröivää puhetta hiljaisemmalla äänellä puhuttu jakso } \\ € \text { Łana€ } & \text { hymyilevällä äänellä puhuttu jakso } \\ \downarrow & \text { nuolen jälkeinen sana tai tavu lausuttu ympäröivää puhetta matalammalla äänellä } \\ \uparrow & \text { nuolen jälkeinen sana tai tavu lausuttu ympäröivää puhetta korkeammalla äänellä } \\ >\text { sana< } & \text { ympäröivää puhetta nopeammin puhuttu jakso } \\ <\text { sana> } & \text { ympäröivää puhetta hitaammin puhuttu jakso } \\ (\text { sana) } & \text { epäselvästi puhuttu sana } \\ (-) & \text { sana tai tavu, josta ei saatu selvää } \\ (()) & \text { kehollinen toiminta } \\ \text { sana } & \text { suomennos }\end{array}$




\section{"CAN I HAVE A BLACK MARKER PEN?" REQUEST SEQUENCES IN RUSSIAN CLIL METHODOLOGICAL INSTRUCTION IN PRIMARY EDUCATION}

Maarit Kaunisto, University of Helsinki

The aim of my study is to examine the request sequences made by Finnish-speaking young learners interacting in a CLIL classroom where the language of instruction is Russian. The empirical data consists of videos of natural classroom interaction, recorded over a period of two years. The data has been analyzed by the means of conversation analysis. Requests are considered as adjacency pairs, where the first pair part is composed usually of a request from the pupil, and the second pair part of approval or rejection from the teacher. The theoretical framework consists of sociocultural and situational learning theories, which emphasize cooperation, participation in interaction with the teacher and the peers, and the long-term socialization of the learning community. The analyzed examples in the data show that this is probably due to the internalization of the language agreement, meaning that the pupils were required to perform their requests only in the target language. The data sets show that the number of the requests in the target language increases even during the first year. The data shows also that over time the students were using creatively the formulaic frames provided by the teacher. All in all, the language-focused analysis of the classroom at a microlevel provides a crucial information on how a language learning community provided with authentic learning situations is built and how important the participation and the use of the target language, even with little language skills, is to the language acquisition.

Keywords: classroom interaction, CLIL, conversation analysis, formulaic frame, request, Russian 